\title{
THE NOTARY SERVICE - JUSTICE SERVICES
}

\section{Emine Zendeli}

South East European University, Faculty of Law, e.zendeli@seeu.edu.mk Arta Selmani-Bakiu

South East European University, Faculty of Law, arta.selmani@seeu.edu.mk

DOI: $10.1515 /$ seeur-2017-0010

\section{Abstract:}

The aim of this study is to explore the role and the importance of the notary service in the process of dejudicialization of the judicial-civil protection. In this context, this paper first of all attempts to examine the extent to which the issues from the traditional competence of the court (usually non-litigious) have been transferred to notary publics and the possibilities of further extension of this transfer. The judicial framework for the transfer of these issues from the court competences to that of notary publics has been decided by the Law on Non-Litigious Procedure (2008). In supporting this law, the notary publics undertook the realization of a series of activities in this field, namely in the field of inheritance. In this respect, the idea of this paper was to try to identify other judicial issues that could perhaps be entrusted to the notary publics in the future, by carrying out a judicial-political assessment of the public interest to transfer the resolution of certain issues to notary publics' competences with the aim of facilitating the judicial circulation and increasing judicial security.

Keywords: notary public, notary service, non-litigious procedure, dejudicialization 


\section{Introduction}

The notary public activity and notary service are important categories of the modern judicial circulation. This public service is exercised by notary publics, who appear as autonomous and independent holders of the notary service within the judicial system of a country.

The profession of notary publics is an old profession of a jurist, and it dates back to Roman law, namely the third century A.D., when the public servant, known as tabellio, appeared for the first time. He used to compile written documents in a certain form, through which he verified the agreements and statements of Roman citizens, which were used for the realization of judicial circulation (Tanaskovic 2003, p. 37).

Since then, through the medieval age, the role of notary publics in European countries and other places in the world has developed permanently.

Within the boundaries of the Kingdom of Yugoslavia, the category of the notary public was for the first time acknowledged with the Law on Notary (1930). After the collapse of the judicial-constitutional system of the then Kingdom of Yugoslavia in 1944, this profession lost importance and was gradually removed from practice. This diminishing to total disappearance of the profession of notary public is explained by the fact that in the monist system the private property was reduced to the smallest possible extent, while there is no doubt that the role of notary public comes into play exactly in the free judicial-civil relationships, which are closely related to the private property and the rights that derive from it.

After the collapse of the monist system and the establishment of judicial democratic systems by the end of the twentieth and the beginning of the twenty-first century, the function of notary publics was revived in all of the former SFRY republics, including the Republic of Macedonia.

In the judicial system of the Republic of Macedonia, the institution of 'notary public' was promoted in the provisions of the Law on performing notary activities of 1996 ("Official Gazette of the R.M." no. 59/96, 25/98, $06 / 02$ and 66/06) and within this time period, it was slowly but surely placed in its deserved position.

By utilizing positive experiences of comparative systems, which implement the Latin continental model of notary, the Republic of Macedonia has adopted free notary, in terms of the Latin model, which is an integral part of the judicial liberal-democratic order. The preference of the Latin model is based on the 
attention that this model pays to the prevention of disputes outside the court; respecting the rule of law state; judicial security; protection of the right to freedom, especially the freedom of private property; the social state principle; the subsidiarity principle and consumer protection.

The notary in the Republic of Macedonia is organized according to the territorial principle, i.e. according to the territory of principal courts. According to this principle, there should be one (1) notary public in 20,000 inhabitants (Article 8, Paragraph 5 of the Law on Notary ("Official Gazette of the R.M." no. $55 / 07)$. The first notary publics in the Republic of Macedonia began their work in June 1998, whereas in the same year the Independent Notary Chamber was also established. Since 2001 it has been an equal member of the International Union of Latin Notaries (IULN). IULN is an international association that gathers the notary chambers of 76 states, in which this judicial institution is implemented.

The main aim of the Notary Chamber is to maintain the autonomy and independence of notary publics, as public servants, during the practicing of public authorizations, as well as safeguard the honor and reputation of the notary publics and the function of the notary in general. Today, the notary service in the Republic of Macedonia counts 180 notary public offices across the country (Notarius, Notary Chamber of the Republic of Macedonia, no. 23, p. 103).

\section{Notary within the legal framework of the Republic of Macedonia}

The notary is an independent public service that carries out works related to public authorizations, based on the law and the request of citizens, state bodies, legal persons and other interested institutions (Article 2, Paragraph 1, Law on Notary ("Official Gazette of the R.M." no. 55/07).

The institution of the notary in the Republic of Macedonia was for the first time established with the Law on performing notary activities of (1996). It was determined that a series of non-litigious issues be transferred from the traditional court competence and the competence of administrative bodies to the competence of notary publics. By transferring some of the non-litigious issues from the competence of the court to the competence of notary publics, the category of the latter gained new dimensions by rising up to a far more important figure of the modern judicial circulation. However, in addition, the unloading of the court from trying to find a solution to certain non-litigious issues, promoted a new tendency of the dejudicialization (or reversal of 
judicialization ) of judicial civil protection within the judicial system of the Republic of Macedonia.

The installation of the institution of the notary in the Republic of Macedonia reflected positively on the functioning of the judicial system in general. The notary service undoubtedly influenced the facilitation of judicial circulation, the efficiency of the work of courts, the increase of judicial security, the prevention of dispute creation, namely their easier resolution, etc.

The notary service has created the opportunity of providing certain services, which were not available before, and more importantly, it has influenced the advancement of what they call preventive judicial protection.

In 2007, the Law on Notary was revealed. Apart from terminological changes, it also introduced a series of new provisions. Special attention has been paid to provisions through which the control of the work of the Notary Chamber and notary publics themselves in the Republic of Macedonia is realized. Concretely, the notary public is obliged to report corruption cases if $\mathrm{s} / \mathrm{he}$ ascertains such during his/her servicing. In this respect, special influence on the new Law on Notary was exercised by the Law On Money Laundering Prevention And Other Criminal Proceeds And Financing Terrorism (Law On Money Laundering Prevention And Other Criminal Proceeds And Financing Terrorism ("Official Gazette of the R.M.” no. 4/2008)).

Under the impact of this law, the Law on Notary has envisaged certain rules through which the notary public is obliged to report any suspicious activity connected to money laundry or client bribery/corruption. Through legal provisions, the development of disciplinary measures and procedure has been rigorously determined, including the possibility of dismissing the notary public in cases when s/he has caused a damage amounting at 50,000€ to his/ her client through his/her own actions. (Article 16, Paragraph 1, Item $f$ of the Law on Notary ("Official Gazette of the R.M." no. 55/07)

In order to ensure better protection for the citizens, namely in order to create opportunities for compensation for the damage caused by the notary public, the Law on Notary obliges the notary public to conclude an insurance contract amounting at 50,000 $€$ for potential damage(s) that $\mathrm{s} /$ he may cause to his/ her clients. (Article 12, Paragraphs 1 and 2 of the Law on Notary ("Official Gazette of the R.M." no. 55/07). 


\section{The role of the notary public in the judicial system in the Republic of Macedonia}

The dynamics, complexity and insecurity that associate the circulation of goods and services in the modern market economy, require the engagement of notary publics. Through his/her services, the notary public provides security, simplicity and low costs in terms of regulating the judicial-civil relationships. The notary public is able to provide that intensity of judicial protection, which courts of law can only after the resolution of the dispute within a legal procedure, at the moment of the binding of the judicial work and the definition of relations between the parties involved. Services provided in the simplest possible way by a single body, as is the notary public, avoid bureaucratic procedures and provide moral warranty for the citizens.

The notary is a complex institution that supplies the judicial order of a country and its citizens with necessary services, with private and public acts, with finalization of important judicial actions, with the emergence, modification, resolution and termination of legal consequences that arise in the civil and commercial judicial circulation (Tutulani- Semini, 2008, p. 5). The notary provides a wide spectrum of judicial services. The primary traditional role of the notary publics includes the following:

- Official compilation and release of documents on judicial affairs

- Official compilation and release of documents on statements and facts upon which rights are based

- Official verification of private documents

- Admission of documents, money and other precious items for protection, with the aim of handing them in to other people or competent bodies, which according to the order of the court or other public bodies, implement procedures determined by law (Article 4, Paragraphs 1 and 2 of the Law on Notary ("Official Gazette of the R.M." no. 55/07).

By engaging in their primary role, namely, by preparing and verifying documents with qualitative content, as well as in their role as people who enjoy public trust (and this is exactly why documents gain the importance of publicly verified documents) (Article 4, Paragraph 3 of the Law on Notary ("Official Gazette of the R.M." no. 55/07)), notary publics guarantee judicial security, prevent the emergence of disputes, namely facilitate their resolution (preventive function), etc.

The importance of the role of notary publics comes out especially in the conclusion of judicial works, for whose validity, the law has provided the form of notarial acts. Thus, the form of a notarial act is obligatory in: 
- Contracts on regulating property relations of marital and extra-marital spouses,

- Contracts on gifts without delivering the item,

- Acts of creation, organization, dismissal, statutory changes of judicial persons that exercise economic activities, institutions, foundations, apart from trade associations,

- Judicial works undertaken by blind and/or deaf people, who cannot read and/or write, or dumb people who are not able to write

- Contracts which enable the disposal of the wealth of underage children or persons who have been denied or limited the capacity to act, as well as in all other cases determined by law Article 42, Law on Notary ("Official Gazette of the R.M." no. 55/07).

By enabling the notarial act to have the feature of a public document (validity), especially the feature of an enforcement document, the avoidance of the whole litigious procedure is made possible. The notarial act will have the quality of an enforcement document if a certain obligation for doing (facere) is verified with it, and for which parties concerned can agree upon, as well as if it contains the debtor's statement, through which s/he agrees that based on this act, the request can be realized, namely the forceful bailiff can be carried out (Article 4, Paragraph 3 of the Law on Notary ("Official Gazette of the R.M." no. 55/07). This enables good, fast, easy and economic protection of rights. This represents a great advantage for the citizens in terms of the protection of their rights, whereas on the other hand, it affects the strengthening of the role and the service of notary publics.

The role of notary publics gains importance when it comes to the area of transferring rights to real estate, inheritance (testament, procedures for reviewing inheritance); family issues (nowadays in many European countries, the notary public plays the main role in litigious procedures of divorcing married couples). S/he records one's wealth (property), compiles the act of sharing real estates, agreements on liquidity, contracts between spouses and then delivers all of these to the court of law (Art, 423, 424, Code civil, Livre III, Titre V, Chapitre I, Section I,; Art. 1410, 2033, BGB-Bürgerlicher Gesetzbuch, Neuste Fassung, Köln; (Article 184, 449, ZGB-Schweizerisches Zivilgesetzbuch vom 10. Dezember 1907 (Stand am 5. Dezember 2008)).

In western European countries as well as in most of countries in transition, the role of notary publics is especially important in the area of consumer protection as well. 


\section{The function of the notary public in the judicial system in the Republic of Macedonia}

During the realization of their duties and tasks, notary publics carry out some functions that represent the pillars of the functioning and liberalization of the judicial democratic system. The function of notary publics is strongly emphasized in terms of the acceleration of the judicial circulation, protection of clients' interests and facilitation of the work of judicial bodies.

The primary function that derives from the engagement of notary publics in the realization of their duties determined by law is the acceleration of the judicial circulation. Modern market economy is characterized by a dynamic circulation of goods, services and capital. The pace at which economic circulation is developed directly determines the pace of judicial circulation. Therefore, in our modern world the interest of accelerating judicial circulation in all of those areas that are closely connected to the market of goods, services and capital is highly emphasized. In this respect, the function of the notary public comes to play, and it is even considered as the most preferred, having in consideration the relatively easy procedures of providing judicial services. Traditionally, parties in a contracting relationship negotiated in advance and then they would go to the lawyer to compile the contract itself and then to the court of law for its verification. The participation of the notary public in this rapport has made it possible to realize all the three mentioned steps simultaneously in the notary public's office (Tanaskoviç, 2003, p.39). This not only facilitates and simplifies the procedure, but also accelerates it at large.

The possibility of the notarial act for having the power of an enforcement document affects a lot the acceleration of judicial circulation. Based on the enforcement document, parties have the possibility to agree, at the moment of concluding the contract, about its direct enforcement without the need for a legal procedure (Article 43, Paragraph 1 of the Law on Notary ("Official Gazette of the R.M." no. 55/07).

Some other characteristics of the notarial act also influence the acceleration of judicial circulation, e.g. clarity of reciprocal obligations of the parties involved, their equality, etc.

During the provision of services by the notary public, his/her function as a protector of the interests of the parties concerned is also revealed. Notary services are carried out independently, professionally and equitably, based on the law, various different provisions as well as international conventions ratified in line with the constitution. Notary publics' independence and 
fairness represent fundamental characteristics of the notary services and are in the interest of proper and unhindered functioning of the judicial system (Article 2, Paragraph 3 of the Law on Notary ("Official Gazette of the R.M." no. 55/07).

Notary public's independence refers to the realization of the notary service as a member of the free profession. Based on his/her official mission, the notary public undertakes certain actions personally and with complete personal responsibility, being always in the interest of concerned parties at whose request $\mathrm{s} / \mathrm{he}$ is engaged, as well as in the interest of the society as a whole.

As regards notary public's neutrality (fairness), it refers to the fact that the notary public does not have the right to give advantage to any of the parties and place either of them in a more favorable position. During the provision of notary services, the notary public has to remain neutral, i.e. to play the role of the entrusted subject for any party that seeks the said service. The notary public is not a party in the procedure; rather $\mathrm{s} / \mathrm{he}$ is a sui generis first level body, who steps in with the aim of protecting the public interest, namely guarantee security in judicial circulation. The aim of his/her participation is to professionally and qualitatively ensure the omnipotence of judicial works thus preventing the emergence of disputes. Every court decision can have undesirable consequences and responsibility for the notary public and can lead to compensation for the damage caused to the client, because the state does is not held responsible for the actions of notary publics. This is about professional civil responsibility for the damage caused by the notary public. The civil responsibility places the holder of a public function against the user of their services and aims at ensuring compensation for those who suffer from harmful consequences because of professional errors (Дабовиќ Анастасовска, 2013, 11).

Within the framework determined by law, the notary public is obliged to account for the interests of any party equally and neutrally, whereupon he has to advise the parties and make sure their free will is verified, as well as inform them on judicial consequences of the actions they are about to undertake. The notary public has no right to mediate in the conclusion of the judicial work, and even less to guarantee for its fulfillment. Unlike the lawyer, who always defends the interests of one of the parties, i.e. undertakes legal actions based on the client's authorization and has the right and is obliged to undertake any action, within the legal framework, that would benefit the concerned party, the notary public does not have the right to incline towards any of the parties involved, act subjectively, or be led by an individual/personal benefit 
or damage that would come as a result of the performance of his/her official tasks and duties (Article 3 of the Law on Notary ("Official Gazette of the R.M.” no. 55/07).

In order to defend the clients' interests, the legislation has determined certain forms for some statements of will and certain judicial works. The form of the notarial act is the harshest form, provided in judicial systems that recognize this institution. Through this form, prevention from possible inequality that could be caused by the varying level of education and judicial culture of the parties and their different material situation is ensured. The legislation has also envisaged the form as a mechanism through which it is attempted to give the same importance to the rights and obligations of both contracting parties, which in turn ensures their equality in the judicial circulation.

The function of protecting the parties' interests comes to play in the phase of the discussion with them. Through his neutrality, the notary public provides security in terms of putting the essence of the judicial work between parties right, taking into consideration their interests equally, though they are quite often contradictory. During the discussion that is carried out between the notary public and the parties, before the notarial act has been compiled, the notary public is obliged to provide the parties all the necessary pieces of advice (Article 44, Paragraphs 1 and 2 of the Law on Notary ("Official Gazette of the R.M." no. 55/07)). This advice is of crucial importance because it has been provided by a neutral and materially uninterested subject. In order to respect the fairness principle, the notary public has to help the economically weaker party.

In the spirit of protecting the parties' interests is the provision according to which the notary public will be dismissed, if s/he him/herself, his/her spouse, his/her parents or children are parties during the editing of the notarial act or the solemnization of the private document (Article 29, Paragraph 1 of the Law on Notary ("Official Gazette of the R.M." no. 55/07).

Finally, the compiled document by the notary public in accordance with the form determined by law that has the seal and signature of the notary public, not only bears the burden of proof on the side of the one who claims the opposite of what the document is saying, but also has extraordinary proofing power and is difficult to be disputed. Therefore, notarial acts provide a high level of protection for the party that refers to them (Tanaskoviç 2003, p. 40).

The notary service largely influences the facilitation of the work of judicial bodies. This can be achieved in several ways: 
- Through the prevention of court disputes

- Through attempts to avoid legal procedures in cases when it comes to such

- Through cooperation with courts of law and overtaking of a portion of the court functioning (Tanaskoviç 2003, p. 43).

- Unlike the judge, who decides upon the civil judicial dispute, the role of the notary public is to act in advance. This means that the notary public acts in a preventive way, in order to avoid the emergence of the dispute itself. The notary public influences in the prevention of disputes since the discussion phase that he undergoes with the parties before compiling the notarial act. In this case, the notary public insists on an agreement related to the disputing issue between the parties with contradicting views. As a neutral advisor, s/ he is obliged to seek for the necessary balance and explain to both parties the volume and the character of undertaken obligations. These actions of the notary public are very important in preventing legal disputes, which quite often derive from acts in which the deadlines have not been met, are unclear or incomplete.

- The notary public, as a person that enjoys public trust, influences the adjustability of the parties' private interests with the public interest expressed by law, which is again in the spirit of preventing disputes. In modern judicial systems, the function of the notary publics is becoming more and more important, as e facilitator and mediator between parties involved. As e neutral person and holder of public authorizations, s/he contributes in the avoidance of conflicting situations through his/her advice and remarks addressed to parties in question. All of this activity performed by the notary public is oriented towards the realization of his/her obligation that even the party that lacks judicial culture is able to understand the explanations, advice and remarks related to the judicial consequences of the affair to be concluded. In this way, $\mathrm{s} / \mathrm{he}$ helps the parties to regulate their relationships in a qualitative manner. All of this creates the possibility of totally avoiding or minimizing the threat of the emergence of disputes and everlasting and expensive procedures in the direction of their resolution. This preventive function is increasingly taking the dimensions of a very important factor of stability and harmonious relations between citizens.

- The cooperation of notary services with courts of law is strongly reflected in the importance the notarial act has in a legal procedure. During the compilation of the notarial act, the notary public undertakes certain actions, which free the court from the need of undertaking certain investigations in advance. Therefore, the notary public is obliged to store not only the notarial act itself, but rather all other proofs connected to the realized process as such (personal data of parties, age, ability to conclude an agreement or compile a testament, etc.). The notarial act which serves as evidence before court authorities in a legal procedure, facilitates the proofing process because it presents non-litigious evidence on the accord that has been made between the parties as well 
as the time and place of the emergence of the rights and obligations of the parties contained in the act.

The cooperation of notary services with courts of law is seen on the communication of motions by the court to the parties (Article 25 of the Law on Litigious Procedure ("Official Gazette of the R.M. no. 79/2005)), the performance of notary publics as entrusted by the court, etc. (Article 131 of the Law on Non-Litigious Procedure ("Official Gazette of the R.M. no. 18/2008). If we refer to the latest legislative changes, the cooperation with courts of law is carried out when the notary public, at the request of the court of law, appears as a representative of the persons unable to act or of the missing ones. Some actions by the notary public are carried out with supervision by the court of law. These include: evidencing of property and wealth, sharing the property/wealth based on the consent or without the consent of parties concerned, public sale for insurance claims,etc.

\section{Conclusion}

In these recent years, we are witnessing a trend of gradual transfer of duties from the non-contentious jurisdiction to the notary public service, which certainly being influenced from the comparative experiences will continue as a part of a wider de judiciary process, in which the process of delivery of Civil and Legal protection is undergoing. This process is as a result of overload of the courts and difficulties in financing and organization of their activity on one hand, respectively, the positive experiences gained by various jobs within the competence of the courts that so far have been given to notaries.

In connection with the discharge of the courts and transfer of cases under the competence of notaries, a question raises about non-judiciary limits, respectively, which litigation cannot be entrusted to other non-judicial bodies. The elements of this limit can be found in the available character of legal relations, in respect to which legal protection should be provided, respectively, with agreement of legal entities, instead of the courts, their disputes and other legal issues and services to be resolved by other authorities, or persons.

In order to achieve desired results in the field of providing legal protection, it would be good if the Constitution determines the possibility that some jobs which are in the competence of the court, to be entrusted by law to persons who do not have quality of the court (judicial advisors, and other court officials), respectively, other persons with public authority outside the courts, which in view of the organizational and functional aspect would ensure independence and objectivity that is provided to the courts. In this 
way we could obtain the constitutional legal basis for transferring certain cases from court's jurisdiction to other services, in which except notaries it is possible to be involved," public bailiffs, and other persons who have not judge quality, eg attorneys and other persons with legal background, but even people who do not have the legal background, but who would be entrusted the resolution of disputes and other legal matters with little social significance.

Notaries de lege lata, within their classic activities would carry certain mediation characters, respectively would offer assistance to parties to regulate their mutual relations with the preparation of certain legal instruments. In this case the goal would be to expand the competence of notaries that are realized through the transfer of other issues from non-contentious judicial, and gain increasingly in the importance as mediators of their position as trusted monitors and impartial to the parties.

It would be nice if from courts competences that are under the jurisdiction of notaries and other persons mentioned above, are transferred some other issues, such as: acceptance of maternity and paternity before a notary public; divorces by agreement before a notary public; issues alimony, provision of evidence or commissioned notaries, which would make possible for the courts instead of seeking the viewing or any other evidence, to even hear the witness by court order, and allocate a notary for this purpose. The jurisdiction of the notary could also be transferred: regulation of relations between the co-separation of the joint, contentious trade procedures, regulation of boundaries, public records etc..

\section{References}

- Дабовиќ Анастасовска,J. (2013). Професионална одговорност на нотарите за штета $u$ должност за задолжително осигурување, Нотариус бр. 23, p.11-30

- Tanaskoviç, Z. (2003) Funkcija javnog beleżnika (notara) u savrenmenim pravnim sistemima. Pravni informator, br 1

- Tutulani- Semini, M. (2008). Relativizimi i lirisë së profesioneve të lira në funksion të një shërbimi "absolutisht” në të mire të qytetarëve dhe në përputhje me ligjin. Noteria, Revista shqiptare për studime ligjore, Tiranë

- Law on performing notary activities of 1996 ("Official Gazette of the R.M." no. 59/96, 25/98, 06/02 and 66/06)

- Law on Notary (“Official Gazette of the R.M." no. 55/07)

- Law on Litigious Procedure („Official Gazette of the R.M” no. 18/2008);

- Law on Non- Litigious Procedure („Official Gazette of the R.M” no. 79/2005); 
- Law On Money Laundering Prevention And Other Criminal Proceeds And Financing Terrorism ("Official Gazette of the R.M." no. 4/2008)

- BGB-Bürgerlicher Gesetzbuch, Neuste Fassung, Köln

- Code civil, Livre III, Titre V, Chapitre I, Section I,

- ZGB-Schweizerisches Zivilgesetzbuch vom 10. Dezember 1907 (Stand am 5. Dezember 2008) 